OPEN ACCESS

Edited by:

Tiina Tosens,

Estonian University of Life Sciences,

Estonia

Reviewed by:

Christiane Werner

Albert Ludwig University of Freiburg,

Germany

Miguel Portillo-Estrada,

University of Antwerp, Belgium

*Correspondence:

Massimiliano Tattini

massimiliano.tattini@ipsp.cnr.it

Specialty section:

This article was submitted to

Functional Plant Ecology,

a section of the journal

Frontiers in Plant Science

Received: 13 April 2017

Accepted: 06 July 2017

Published: 26 July 2017

Citation:

Fini $A$, Brunetti $C$, Loreto $F$, Centritto M, Ferrini F and Tattini $M$

(2017) Isoprene Responses and Functions in Plants Challenged

by Environmental Pressures

Associated to Climate Change.

Front. Plant Sci. 8:1281

doi: 10.3389/fpls.2017.01281

\section{Isoprene Responses and Functions in Plants Challenged by Environmental Pressures Associated to Climate Change}

\author{
Alessio Fini', Cecilia Brunetti2,3, Francesco Loreto ${ }^{4}$, Mauro Centritto ${ }^{2}$, Francesco Ferrini ${ }^{3}$ \\ and Massimiliano Tattini ${ }^{5 *}$
}

\begin{abstract}
${ }^{1}$ Department of Agricultural and Environmental Sciences - Production, Landscape, Agroenergy, University of Milan, Milan, Italy, ${ }^{2}$ Department of Biology, Agriculture and Food Science, National Research Council of Italy, Trees and Timber Institute, Sesto Fiorentino, Italy, ${ }^{3}$ Department of Agrifood Production and Environmental Sciences, University of Florence, Florence, Italy, ${ }^{4}$ Department of Biology, Agriculture and Food Science, National Research Council of Italy, Rome, Italy, ${ }^{5}$ Department of Biology, Agriculture and Food Science, National Research Council of Italy, Institute for Sustainable Plant Protection,

Sesto Fiorentino, Italy
\end{abstract}

The functional reasons for isoprene emission are still a matter of hot debate. It was hypothesized that isoprene biosynthesis evolved as an ancestral mechanism in plants adapted to high water availability, to cope with transient and recurrent oxidative stresses during their water-to-land transition. There is a tight association between isoprene emission and species hygrophily, suggesting that isoprene emission may be a favorable trait to cope with occasional exposure to stresses in mesic environments. The suite of morpho-anatomical traits does not allow a conservative water use in hygrophilic mesophytes challenged by the environmental pressures imposed or exacerbated by drought and heat stress. There is evidence that in stressed plants the biosynthesis of isoprene is uncoupled from photosynthesis. Because the biosynthesis of isoprene is costly, the great investment of carbon and energy into isoprene must have relevant functional reasons. Isoprene is effective in preserving the integrity of thylakoid membranes, not only through direct interaction with their lipid acyl chains, but also by up-regulating proteins associated with photosynthetic complexes and enhancing the biosynthesis of relevant membrane components, such as mono- and di-galactosyl-diacyl glycerols and unsaturated fatty acids. Isoprene may additionally protect photosynthetic membranes by scavenging reactive oxygen species. Here we explore the mode of actions and the potential significance of isoprene in the response of hygrophilic plants when challenged by severe stress conditions associated to rapid climate change in temperate climates, with special emphasis to the concomitant effect of drought and heat. We suggest that isoprene emission may be not a good estimate for its biosynthesis and concentration in severely droughted leaves, being the internal concentration of isoprene the important trait for stress protection.

Keywords: climate change, drought and heat stress, fast-growing plants, isoprene biosynthesis vs. isoprene emission, membrane protection, stomatal conductance 


\section{WHY ISOPRENE EMISSION MAY BECOME MORE RELEVANT IN A DRIER AND WARMER CLIMATE?}

Isoprene (2-methyl-1,3-butadiene), the major volatile organic compound (VOC) emitted by biogenic sources, has driven attention because of its impact on atmospheric chemistry and climate (Atkinson, 2000). Globally, 0.5-0.6 Pg C are emitted as isoprene annually, accounting for $50 \%$ of total biogenic volatile organic compounds (BVOCs), and for 30\% of non-methane hydrocarbons emissions (Guenther et al., 2006, 2012). Isoprene is highly volatile and reactive, and its emission by terrestrial plants can substantially affect the concentration of tropospheric ozone $\left(\mathrm{O}_{3}\right)$, the lifespan of methane, and the nucleation, condensation or coagulation of secondary aerosol(s) (Pike and Young, 2009; Ying et al., 2015). In the present global change scenario, isoprene emission $\left(\mathrm{Iso}_{\mathrm{e}}\right)$ is of major concern for several reasons.

First, urban population is expected to increase by approximately $70 \%$ by 2050 (United Nations, 2015), and growing megacities are hotspots of atmospheric gaseous and particulate pollutants, with economic, sanitary and social consequences (Baudic et al., 2016). For example, air pollution, particularly tropospheric $\mathrm{O}_{3}$ and particulate matter, was responsible of 34,143, and 17,800 excess deaths, in Italy and France, respectively, during 2010 (Global Burden of Disease [GBD], 2013; Mori et al., 2015; Baudic et al., 2016). While at null nitrogen oxide $\left(\mathrm{NO}_{\mathrm{x}}\right)$ concentration, isoprene can even lower tropospheric $\left[\mathrm{O}_{3}\right]$, when levels of $\mathrm{NO}_{\mathrm{x}}$ are high, a single isoprene molecule leads to the formation of several $\mathrm{O}_{3}$ molecules (Zeng et al., 2008). In urban areas, where $\mathrm{NO}_{\mathrm{x}}$ concentration is high (the so-called $\mathrm{NO}_{\mathrm{x}}$-saturation regime), $\mathrm{O}_{3}$ production is highly responsive to VOCs (Sillman, 1999; Deguillaume et al., 2008; Ling et al., 2014). Thus, to limit $\mathrm{O}_{3}$ pollution in $\mathrm{NO}_{\mathrm{x}}$-saturated urban sites, policy actions aimed at reducing VOC emission may be more effective and easier to actuate than the policies aimed at decreasing $\mathrm{NO}_{\mathrm{x}}$ concentration (Baudic et al., 2016; Khedive et al., 2017).

Second, conversion of isoprene-emitting forest to lowemitting cropland to match the increasing demand for food, globally decreased isoprene concentration by $15 \%$ during the last century (Lathiere et al., 2010). However, the ongoing shift to bioenergy crops (e.g., giant reed) and short rotation forests (e.g., poplar) will likely increase isoprene load, particularly at regional scale (Hardacre et al., 2013; Sharkey and Monson, 2014). For example, in South East Asia, the 27 Mha expansion of land cultivated with oil palm, which can emit three times more isoprene than the native crops (Fowler et al., 2011), increased surface $\mathrm{O}_{3}$ by $11 \%$ (Ashworth et al., 2012). Similarly, the expansion of short rotation forests (mainly poplar) in the temperate northern hemisphere triggers the increase in isoprene burden predicted for boreal Eurasia, North America, and China, where $\mathrm{O}_{2} / \mathrm{O}_{3}$ mixing ratios are expected to increase up to 2.26 ppb (Ashworth et al., 2012; Hardacre et al., 2013; Zenone et al., 2016).

Third, species from all taxonomic groups have spread around the world, mostly because of human activities. These biological invasions may alter the emission profile of volatiles. For instance, Llusià et al. (2010) have found a lower emission of isoprenoids in native species growing in Hawaii, compared to co-occurring alien species. This was attributed to the lower emission potential of native species relative to aliens, within any given phylogenetic line, though further research is required to upscale this phenomenon. Similarly, tree genera characterized by extensive speciation and hybridization have been reported to emit isoprene more frequently than their phylogenetically nearest non-speciose genera (Dani et al., 2014). Isoprene, being highly volatile (Henry's law constant of 7,780 $\mathrm{Pa} \mathrm{m}^{3} \mathrm{~mol}^{-1}$, Harley, 2013), is a 'quick' metabolite capable of improving photosynthetic performance under physiological (non-stressful) (Pollastri et al., 2014) and under transient, usually mild-to-moderate, stress conditions (Loreto and Fineschi, 2015; Maja et al., 2016). Furthermore, it provides protection against generalist pests (Llusià et al., 2010; Harrison et al., 2013); thus alien species, which lack specialist parasites, may greatly benefit from being emitters (Laothawornkitkul et al., 2008; Mithofer and Boland, 2012).

Finally, $\mathrm{Iso}_{\mathrm{e}}$ is exponentially linked to temperature, thus global warming is expected to increase the load of volatile compounds (Fares et al., 2011; Lahr et al., 2015). Nonetheless, a conclusive picture of the effect of climate change on $\mathrm{Iso}_{e}$ and hence on the chemistry of the atmosphere is far from being drawn, as the wide range of co-occurring environmental factors (e.g., rising $\mathrm{CO}_{2}$ ) may have synergic or antagonistic effects on isoprene biosynthesis (Dieleman et al., 2012).

We focus our discussion on the effects of concomitant stress factors on the biosynthesis and emission of isoprene, with the aim of further exploring isoprene functional roles in hygrophylic plants challenged by 'novel' environmental pressures associated to climate change in temperate climates (e.g., Cfa, Cfb in Koppen Geiger classification).

\section{EXPLORING THE SIGNIFICANCE OF ISOPRENE IN PLANTS CHALLENGED BY STRESS}

The functional reasons for $\mathrm{Iso}_{\mathrm{e}}$ are still a matter of debate (Sharkey and Monson, 2017). It was hypothesized that isoprene biosynthesis $\left(\mathrm{Iso}_{\mathrm{s}}\right)$ evolved as an ancestral mechanism in plants adapted to high water availability, to cope with transient and recurrent oxidative stresses during their water-to-land transition (Vickers et al., 2009; Loreto et al., 2014). Consistently the tight association between $\mathrm{Iso}_{\mathrm{e}}$ and species hygrophily suggests that Iso $\mathrm{e}_{\mathrm{e}}$ may be a favorable trait to cope with occasional exposure to stresses in mesic environments (Harrison et al., 2013; Monson et al., 2013; Loreto et al., 2014). Instead, xeric evergreen species inhabiting harsher environments, which require constitutive emissions over a longer time-scale level, generally produce compounds less volatile than isoprene, such as monoterpenes and sesquiterpenes (Loreto and Fineschi, 2015). Fast-growing hygrophilous Quercus species, such as most North American and some European oaks (e.g., Q. robur) emit isoprene, whereas isoprene is replaced by monoterpenes in xeric oaks, such as $Q$. ilex 
and Q. suber (Loreto et al., 1998, 2009; Sharkey et al., 2008). This conforms the notion that marked differences in gene sequences encoding isoprene synthase have been found not only between plant groups, but also within each individual group (Dani et al., 2014), and suggests that environmental conditions may have contributed shaping the evolution of isoprenoid synthesis (Monson et al., 2013).

Several fast-growing, isoprene-emitting plants have moved to areas with harsher climate conditions than those of habitats they evolved (Owen et al., 2013). In many instances, extended periods of rainfall scarcity, which usually occur in combination with high both solar irradiance and air temperature may pose serious challenges to plant survival, not only to the profitable production of biomass. Furthermore, the suite of morpho-anatomical traits (e.g., low tissue density, thin cuticle, large vessels, high vein density, see Reich, 2014) does not allow a conservative water use in hygrophilic mesophytes and their ability to withstand combined stress conditions may greatly depend on the so-called metabolic plasticity, which mostly involves secondary metabolites (Tattini et al., 2015). There is evidence that the biosynthesis of isoprenoids is stimulated via ROS-signaling (Fanciullino et al., 2014). This may help explain why the biosynthesis of secondary metabolites, particularly of isoprene is generally uncoupled from photosynthesis $\left(A_{\mathrm{N}}\right)$ in drought-stressed leaves (Affek and Yakir, 2003; Loreto and Schnitzler, 2010; Centritto et al., 2011).

The lack of correlation between $A_{\mathrm{N}}$ and isoprene biosynthesis/emission becomes clearer when plants concurrently face multiple stresses. Indeed, there is compelling evidence that carbon sources alternative to recently fixed $\mathrm{CO}_{2}$ may have particular significance when photosynthesis is constrained by stress (Brilli et al., 2007). These alternative carbon sources may include: non-structural carbohydrates (Kreuzwieser et al., 2002; Funk et al., 2004; Schnitzler et al., 2004); phosphoenolpyruvate imported from the cytosol (Rosenstiel et al., 2003; Fortunati et al., 2008; Jardine et al., 2010); re-fixation of respired $\mathrm{CO}_{2}$ (Loreto et al., 2004); isoprenoid precursors from the cytosolic mevalonate pathway (Flügge and Gao, 2005); photorespiratory carbon (Jones and Rasmussen, 1975). Carbon derived from photorespiration may have particularly value in sustaining Iso $_{\mathrm{s}}$ when plants experience intense drought and heat stresses (Jardine et al., 2014). Drought stress depresses photosynthesis to a greater extent than photorespiration (Atkin and Macherel, 2009), particularly at high temperatures (Centritto et al., 2011), while elevated temperatures enhance both the substrate (DMADP) availability and the activity of isoprene synthase (Rasulov et al., 2010). Air temperature mostly regulates Iso $_{\mathrm{s}}$ in plants growing at light intensities that saturate photosynthesis (Monson, 2002; Mayrhofer et al., 2005; Fares et al., 2011; Niinemets and Sun, 2015), since Iso $\mathrm{e}_{\mathrm{e}}$ does not saturate even at very high photosynthetic photon flux density $\left(>2000 \mu \mathrm{mol} \mathrm{m}{ }^{-2}\right.$ $s^{-1}$, Geron et al., 2006; Loreto and Schnitzler, 2010).

In plants concurrently experiencing water and heat stress, stomatal closure reduces latent heat and exacerbates sensible heat load (Tattini et al., 2015). In particular, hygrophilic isopreneemitters steeply close stomata, even at moderate drought, to avoid tissue dehydration (Brilli et al., 2007; Tattini et al., 2015; Velikova et al., 2016). These are the conditions under which isoprene biosynthesis is largely stimulated. Isoprene has been reported to enhance drought resistance of many fast-growing species, including tobacco and poplars. In all cases, isopreneemitting lines showed reduced depression of photosynthesis, and less oxidative damage than non-emitting lines, when exposed to drought (Ryan et al., 2014; Tattini et al., 2014; Vanzo et al., 2017).

\section{ISOPRENE MODE OF ACTION: FACTS AND SPECULATIONS OF AN OPEN DEBATE}

Because isoprene is costly for leaves (20 ATP and 14 NADPH for each molecule of isoprene produced by $\mathrm{CO}_{2}$ fixation through photosynthesis) (Sharkey and Yeh, 2001) the great investment of leaves for $\mathrm{Iso}_{\mathrm{s}}$ under stressful conditions must have functional reasons (Sharkey and Monson, 2017). Isoprene may play multiple functions in countering the detrimental effects of supernumerary photons reaching the chloroplast, when the leaf ability to process radiant energy to carbon fixation is severely constrained by environmental stressors (Loreto and Schnitzler, 2010). Isoprene is effective in preserving the integrity of thylakoid membranes (Velikova et al., 2011, 2015). Populus $\times$ canescens lines where $\mathrm{Iso}_{\mathrm{s}}$ is suppressed displayed reduced photosynthetic electron transport rate (ETR) during heat stress, and did not recover photosynthesis at the level of the corresponding isoprene-emitting lines after relief from stress (Behnke et al., 2007). The protective functions of isoprene on membrane-associated processes (also observed under 'physiological' conditions, Pollastri et al., 2014) may not depend simply on the hydrophobic interaction between isoprene and the lipid acyl chains of membranes (Siwko et al., 2007), as isoprene concentration inside membranes is too low to effectively modulate their bulk lipid phase (Harvey et al., 2015). Benefits for membrane stability associated to $\mathrm{Iso}_{\mathrm{e}}$ may also result from both the up-regulation of proteins associated with photosynthetic complexes (Velikova et al., 2014) and the enhanced biosynthesis of relevant membrane components, such as mono- and digalactosyl-diacyl glycerols and unsaturated fatty acids (Velikova et al., 2015). In simpler terms, isoprene-induced improvement in the use of radiant energy to carbon fixation may reduce the risk of photo-oxidative stress in isoprene-emitting leaves. Protection of photosynthetic membranes may be induced by isoprene indirectly, as isoprene is also known to scavenge reactive oxygen species (ROS) (Loreto and Velikova, 2001; Affek and Yakir, 2002; Velikova et al., 2004). The antioxidant effect of isoprene is especially clear in the case of singlet oxygen $\left({ }^{1} \mathrm{O}_{2}\right)$, the most dangerous ROS in chloroplasts. This effect was empirically demonstrated by Velikova et al. (2004), and has now been theoretically framed (Zeinali et al., 2016). ROS scavenging inside leaves explains the formation of isoprene oxidation products, mostly methyl-vinyl-ketone and methacrolein, in plants exposed to a wide range of stressors, especially heat, in both controlled (Jardine et al., 2012, 2013) and field conditions (Cappellin et al., 2017).

Despite the large body of evidence summarized above, there are open questions that still challenge the idea that isoprene 
might have a definite role in plant protection. Why did only about $20 \%$ of the plants worldwide develop the capacity to emit isoprene? (Loreto and Fineschi, 2015). Why are these plants spread all over biomes and climatic areas (Loreto and Fineschi, 2015), and are not concentrated where stress protection becomes more relevant for securing plant survival, growth, and reproduction?

In many instances, $\mathrm{Iso}_{\mathrm{e}}$ increases under mild to moderate drought, but declines steeply when plants face severe drought (Brilli et al., 2007, 2013; Centritto et al., 2011; Tattini et al., 2014, 2015). Therefore, it has been hypothesized that isoprene plays a beneficial role only in response to mild stress, whereas non-volatile, more stable metabolites, produced through the same metabolic pathway of isoprene (the MEP pathway, i.e., carotenoids and abscisic acid), serve functions of greater significance when plants are challenged by severe stress. This is a revisited formulation of the "opportunistic hypothesis", firstly postulated by Owen and Peñuelas (2005). For example, in Xerophyta humilis, $\mathrm{Iso}_{\mathrm{e}}$ ceased at 5\% RWC, but zeaxanthin replaced isoprene to enhance membrane stability, thus allowing prompt chloroplast re-assembly upon re-watering of this resurrection plant (Beckett et al., 2012). Recent evidence suggests that isoprene may serve antioxidant functions (sensu lato) of increasing significance in plants concurrently challenged by drought and heat. Indeed, the activities of primary antioxidants, such as antioxidant enzymes, and the concentration of zeaxanthin may decrease in high light-exposed plants during the hottest hours of the day, whereas biosynthesis and emission of isoprene are promoted in the same conditions (Brunetti et al., 2015; Tattini et al., 2015).

Isoprene emission might even have a regulatory role, differentially setting the flow of carbon in the MEP pathway along stress progression. The transient increase of isoprene biosynthesis/emission in drought-stressed leaves might serve to use of excess reducing power, limiting the accumulation of dimethylallyl diphosphate (DMADP) and its consequent feedback down-regulation of the whole MEP pathway (Banerjee et al., 2013; Ghirardo et al., 2014). Sustained isoprene formation under stress conditions may also indirectly contribute to increase the carbon flux into the MEP pathway leading to the de novo biosynthesis of foliar abscisic acid, the stress hormone controlling stomatal aperture in drying soil to prevent water loss (Zhang and Davies, 1987). This effect might be exacerbated when plants concurrently face high solar irradiance and temperatures, which are known to increase the availability of DMADP (Mayrhofer et al., 2005; Sharkey and Monson, 2014). Thus, internal isoprene concentration (not isoprene emission) might 'prime for drought stress response, triggering a general protective function that also involves changes in non-volatile isoprenoids, soluble carbohydrates and phenylpropanoids (Tattini et al., 2014). This may sustain the need of large metabolic adjustments of hygrophylic plants suddenly facing the unpredictable pressures imposed by "anthropogenic" planting sites, where microclimates can be very different from those where these species have evolved.

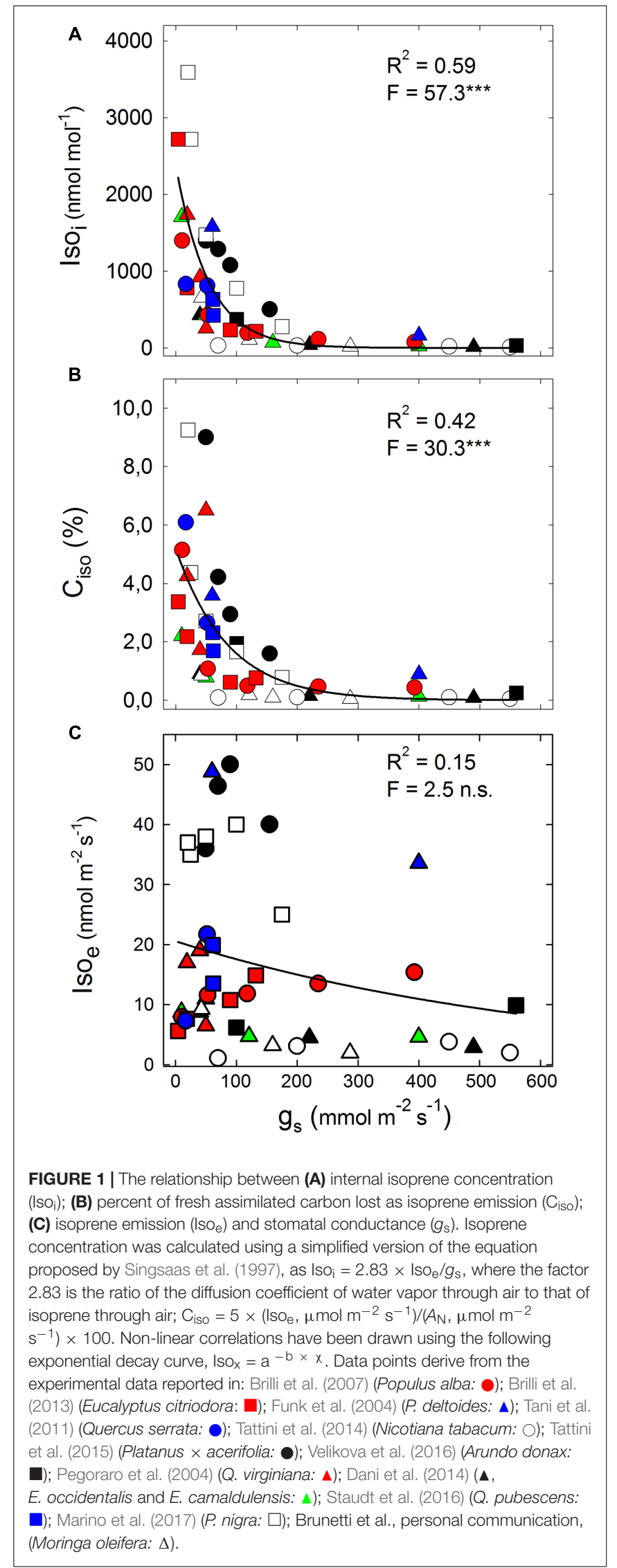




\section{IS ISOPRENE EMISSION A GOOD PROXY OF INTERNAL ISOPRENE AND OF PLANT STRESS RESPONSE?}

Isoprene emission has been usually taken as a good estimate of $\mathrm{Iso}_{s}$, but $\mathrm{Iso}_{e}$ might largely differ from Iso $\mathrm{I}_{s}$, e.g., as consequence of drought-induced declines in stomatal conductance $\left(g_{\mathrm{s}}\right)$. It has been hypothesized that stomata cannot control the emission of VOCs with high Henry's low constant, such as isoprene, even during rapid reductions in $g_{\mathrm{s}}$ (Niinemets and Reichstein, 2003). If $\mathrm{Iso}_{\mathrm{s}}$ remains constant or even increases when stress induces stomatal closure, then the increased gradient between the internal and external concentration of isoprene should compensate for the increased resistance to isoprene outflow. However, under chronic or severe reductions of $g_{\mathrm{s}}$, isoprene concentration inside the leaf $\left(\mathrm{Iso}_{\mathrm{i}}\right.$ ) largely exceeds $\mathrm{Iso}_{\mathrm{e}}$ (Velikova et al., 2016), and $\mathrm{Iso}_{\mathrm{i}}$ might represent a more suitable estimate of $\mathrm{Iso}_{s}$ compared to Iso $_{e}$ (Brunetti et al., 2015; Tattini et al., 2015).

It has been also speculated that lipid membranes are saturated with isoprene even at low emission rates (because isoprene is highly hydrophobic in its nature), and that any increase in Iso $_{s}$ will increase isoprene diffusion through membranes rather than enhancing its membrane concentration (Vickers et al., 2009). However, recent results discussed above revisited this concept and showed that isoprene concentration in membranes is generally low (Harvey et al., 2015). Therefore, it cannot be excluded that steep reductions of $g_{s}$ may induce large accumulation of isoprene inside leaves, on a short time-scale, thereby altering membrane composition (Velikova et al., 2015), while providing efficient antioxidant and priming functions.

The decline in $g_{s}$ is a good proxy of drought stress severity in isohydric hygrophylic plants. The best-fit analysis reported in Figure 1 shows a highly significant exponential decay of $\mathrm{Iso}_{\mathrm{i}}$ with increasing $g_{\mathrm{s}}$ (Figure 1A), because drought stress strongly enhances Iso $_{\mathrm{i}}$ for $g_{\mathrm{s}}<200 \mathrm{mmol} \mathrm{m} \mathrm{m}^{-2} \mathrm{~s}^{-1}$, whereas $\mathrm{Iso}_{\mathrm{i}}$ is unresponsive to higher $g_{s}$. The severity of drought also significantly correlates with the investment of freshly assimilated carbon $\left(\mathrm{C}_{\text {iso }}\right)$ to Iso $\mathrm{s}_{\mathrm{s}}$ (Figure 1B), indicating that a growing fraction of photosynthetic carbon sustains isoprene formation when the stress severely reduces $g_{\mathrm{s}}$. $\mathrm{C}_{\text {iso }}$ has also been widely shown to positively correlate with the unbalance between the ETR and $A_{\mathrm{N}}$ (Morfopoulos et al., 2014). In fact, ETR/ $A_{\mathrm{N}}$ often

\section{REFERENCES}

Affek, H. P., and Yakir, D. (2002). Protection by isoprene against singlet oxygen in leaves. Plant Physiol. 129, 269-277. doi: 10.1104/pp.010909

Affek, H. P., and Yakir, D. (2003). Natural abundance carbon isotope composition of isoprene reflects incomplete coupling between isoprene synthesis and photosynthetic carbon flow. Plant Physiol. 131, 1727-1736. doi: 10.1104/pp.102. 012294

Ashworth, K., Folberth, G., Hewitt, C. N., and Wild, O. (2012). Impacts of nearfuture cultivation of biofuel feedstocks on atmospheric composition and local air quality. Atmos. Chem. Phys. 12, 919-939. doi: 10.5194/acp-12-919-2012

Atkin, O. K., and Macherel, D. (2009). The crucial role of plant mitochondria in orchestrating drought tolerance. Ann. Bot. 103, 581-597. doi: 10.1093/aob/ mcn094 increases as drought become more severe, especially when $A_{\mathrm{N}}$ is constrained by diffusional limitations (at stomatal or mesophyll level) rather than by biochemical limitations, as observed in fastgrowing mesophytes, which are usually strong isoprene emitters (Loreto et al., 2014; Haworth et al., 2016). In contrast, there is a poor correlation between $\mathrm{Iso}_{\mathrm{e}}$ and $g_{\mathrm{s}}$ (Figure 1C). In our survey, $\mathrm{IsO}_{e}$ is almost unresponsive to mild and moderate droughtinduced depressions in $g_{\mathrm{s}}$, in both high (Platanus $\times$ acerifolia, Populus nigra, P. deltoides, on average $\mathrm{Iso}_{\mathrm{e}}$ of $40.0 \mathrm{nmol} \mathrm{m}^{-2} \mathrm{~s}^{-1}$ ) and low isoprene emitters (Eucalyptus occidentalis, Nicotiana tabacum, on average $\mathrm{Iso}_{\mathrm{e}}$ of $\left.4.0 \mathrm{nmol} \mathrm{m} \mathrm{m}^{-2} \mathrm{~s}^{-1}\right)$. In species with intermediate isoprene emission rates (on average $\mathrm{Iso}_{e}$ of $10.8 \mathrm{nmol} \mathrm{m}^{-2} \mathrm{~s}^{-1}$ ), instead, Iso $_{e}$ either declines ( $P$. alba, E. citriodora) or increases (Moringa oleifera) following droughtinduced depression of $g_{s}$. Data of our meta-analysis may help explain why isoprene emission fails representing the intensity of drought and heat stresses in current models (Harrison et al., 2013; Morfopoulos et al., 2013; Sharkey and Monson, 2014). We conclude that $\mathrm{Iso}_{\mathrm{i}}$ and $\mathrm{C}_{\mathrm{iso}}$, representing isoprene accumulation inside leaves, may allow better estimation than isoprene emission of the functional responses of plants to stress. However, we are aware that accuracy of $g_{s}$ measurements is inherently low for $g_{\mathrm{s}}<20 \mathrm{mmol} \mathrm{m}^{-2} \mathrm{~s}^{-1}$ so that calculations of Iso (and to less extent of $\mathrm{C}_{\text {iso }}$ as well) have to be taken with some caution at very severe drought. The issue is of interest and merits further investigation.

\section{AUTHOR CONTRIBUTIONS}

$\mathrm{AF}$ wrote the first and second sections of the manuscript; $\mathrm{CB}$ wrote the second and third sections of the manuscript and conducted to the meta-analysis of data; FL contributed to manuscript writing and carefully reviewed the manuscript; MC and FF carefully reviewed the manuscript; MT drafted the manuscript and wrote section three and four of the manuscript.

\section{FUNDING}

This work was supported by the EU FP7-311929 project (Development of improved perennial non-food biomass and bioproduct crops for water stressed environments - WATBIO)

Atkinson, R. (2000). Atmospheric chemistry of VOC and NOx. Atmos. Environ. 34, 2063-2101. doi: 10.1016/S1352-2310(99)0 0460-4

Banerjee, A., Wu, Y., Banerjee, R., Li, Y., Yan, H., and Sharkey, T. D. (2013). Feedback inhibition of deoxy-D-xylulose-5-phosphate synthase regulates the methylerythritol 4-phosphate pathway. J. Biol. Chem. 288, 16926-16936. doi: 10.1074/jbc.M113.464636

Baudic, A., Gros, V., Sauvage, S., Locoge, N., Sanchez, O., Sarda-Estève, R., et al. (2016). Seasonal variability and source appointment of volatile organic compounds (VOCs) in the Paris megacity (France). Atmos. Chem. Phys. 16, 11961-11989. doi: 10.5194/acp-16-11961-2016

Beckett, M., Loreto, F., Velikova, V., Brunetti, C., Di Ferdinando, M., Tattini, M., et al. (2012). Photosynthetic limitations and volatile and non-volatile isoprenoids in the poikilochlorophyllous resurrection plant Xerophyta humilis 
during dehydration and rehydration. Plant Cell Environ. 35, 2061-2074. doi: $10.1111 / j .1365-3040.2012 .02536 . x$

Behnke, K., Ehlting, B., Teuber, M., Bauerfeind, M., Louis, S., Hänsch, R., et al. (2007). Transgenic, non-isoprene emitting poplars don't like it hot. Plant J. 51, 485-499. doi: 10.1111/j.1365-313X.2007. 03157.x

Brilli, F., Barta, C., Fortunati, A., Lerdau, M., Loreto, F., and Centritto, M. (2007). Response of isoprene emission and carbon metabolism to drought in white poplar (Populus alba) saplings. New Phytol. 175, 244-254. doi: 10.1111/j.14698137.2007.02094.x

Brilli, F., Tsonev, T., Mahmood, T., Velikova, V., Loreto, F., and Centritto, M. (2013). Ultradian variation of isoprene emission, photosynthesis, mesophyll conductance, and optimum temperature sensitivity for isoprene emission in water-stressed Eucalyptus citriodora saplings. J. Exp. Bot. 64, 519-528. doi: $10.1093 /$ jxb/ers353

Brunetti, C., Guidi, L., Sebastiani, F., and Tattini, M. (2015). Isoprenoids and phenylpropanoids are key components of the antioxidant defense system of plants facing severe excess light stress. Environ. Exp. Bot. 119, 54-62. doi: 10.1016/j.envexpbot.2015.04.007

Cappellin, L., Algarra Alarcon, A., Herdlinger-Blatt, I., Sanchez, J., Biasioli, F., Martin, S. T., et al. (2017). Field observations of volatile organic compound (VOC) exchange in red oaks. Atmos. Chem. Phys. 17, 4189-4207. doi: 10.5194/ acp-17-4189-2017

Centritto, M., Brilli, F., Fodale, R., and Loreto, F. (2011). Different sensitivity of isoprene emission, respiration and photosynthesis to high growth temperature coupled with drought stress in black poplar (Populus nigra) saplings. Tree Physiol. 31, 275-286. doi: 10.1093/treephys/tpq112

Dani, S. K. G., Jamie, I. M., Prentice, I. C., and Atwell, B. J. (2014). Evolution of isoprene emission capacity in plants. Trends Plant Sci. 19, 439-445. doi: 10.1016/j.tplants.2014.01.009

Deguillaume, L., Leriche, M., Amato, P., Ariya, P. A., Delort, A. M., Pöschl, U., et al. (2008). Microbiology and atmospheric processes: chemical interactions of primary biological aerosols. Biogeosci. Discuss. 5, 841-870. doi: 10.5194/bgd-5841-2008

Dieleman, W. I. J., Vicca, S., Dijkstra, F. A., Hagedorn, F., Hovenden, M. J., Larsen, K. S., et al. (2012). Simple additive effects are rare: a quantitative review of plant biomass and soil process response to combined manipulations of $\mathrm{CO} 2$ and temperature. Glob. Change Biol. 18, 2681-2693. doi: 10.1111/j.1365-2486. 2012.02745.x

Fanciullino, A. L., Bidel, L. P. R., and Urban, L. (2014). Carotenoid responses to environmental stimuli: integrating redox and carbon controls into a fruit model. Plant Cell Environ. 37, 273-289. doi: 10.1111/pce.12153

Fares, S., Mahmood, T., Liu, S., Loreto, F., and Centritto, M. (2011). Influence of growth temperature and measuring temperature on isoprene emission, diffusive limitations of photosynthesis and respiration in hybrid poplars. Atmos. Environ. 45, 155-161. doi: 10.1016/j.atmosenv.2010.09.036

Flügge, U. I., and Gao, W. (2005). Transport of isoprenoid intermediates across chloroplast envelope membranes. Plant Biol. 7, 91-97. doi: 10.1055/s-2004830446

Fortunati, A., Barta, C., Brilli, F., Centritto, M., Zimmer, I., Schnitzler, J. P., et al. (2008). Isoprene emission is not temperature-dependent during and after severe drought-stress: a physiological and biochemical analysis. Plant J. 55, 687-697. doi: $10.1111 /$ j.1365-313X.2008.03538.x

Fowler, D., Nemitz, E., Misztal, P., Di Marco, C., Skiba, U., Ryder, J., et al. (2011). Effects of land use on surface-atmosphere exchanges of trace gases and energy in Borneo: comparing fluxes over oil palm plantations and a rainforest. Philos. Trans. R. Soc. B 366, 3196-3209. doi: 10.1098/rstb.2011.0055

Funk, J. L., Mak, J. E., and Lerdau, M. T. (2004). Stress-induced changes in carbon sources for isoprene production in Populus deltoides. Plant Cell Environ. 27, 747-755. doi: 10.1111/j.1365-3040.2004.01177.x

Geron, C., Guenther, A., Greenberg, J., Karl, T., and Rasmussen, R. (2006). Biogenic volatile organic compound emissions from desert vegetation of the southwestern US. Atmos. Environ. 40, 1645-1660. doi: 10.1016/j.atmosenv. 2005.11.011

Ghirardo, A., Wright, L. P., Bi, Z., Rosenkranz, M., Pulido, P., RodríguezConcepción, M., et al. (2014). Metabolic flux analysis of plastidic isoprenoid biosynthesis in poplar leaves emitting and nonemitting isoprene. Plant Physiol. 165, 37-51. doi: 10.1104/pp.114.236018
Global Burden of Disease [GBD] (2013). Seattle: Institute for Health Metrics and Evaluation. Available at: http://viz.healthmetricsandevaluation.org/gbdcompare/

Guenther, A., Jiang, X., Heald, C. L., Sakulyanontvittaya, T., Duhl, T., Emmons, L. K., et al. (2012). The Model of Emissions of Gases and Aerosols from Nature version 2.1 (MEGAN2.1): an extended and updated framework for modeling biogenic emissions. Geosci. Model Dev. 5, 1471-1492. doi: 10.5194/gmd-51471-2012

Guenther, A., Karl, T., Harley, P., Wiedinmyer, C., Palmer, P. I., and Geron, C. (2006). Estimates of global terrestrial isoprene emission using MEGAN (Model of Emission of Gases and Aerosol from Nature). Atmos. Chem. Phys. 6, 3181-3210. doi: 10.5194/acp-6-3181-2006

Hardacre, C. J., Palmer, P. I., Baumanns, K., Rounsevell, M., and Murray-Rust, D. (2013). Probabilistic estimation of future emissions of isoprene and surface oxidant chemistry associated with land use change in response to growing food needs. Atmos. Chem. Phys. 13, 5451-5472. doi: 10.5194/acp-13-5451-2013

Harley, P. C. (2013). "The roles of stomatal conductance and compound volatility in controlling the emission of volatile organic compounds from leaves," in Biology, Controls and Models of Tree Volatile Organic Compound Emissions, eds U. Niinemets and R. K. Monson (Berlin: Springer), 181-208. doi: 10.1007/97894-007-6606-8_7

Harrison, S. P., Morfopoulos, C., Dani, S. K. G., Prentice, I. C., Arneth, A., Atwell, B. J., et al. (2013). Volatile isoprenoid emission from plastid to planet. New Phytol. 197, 49-57. doi: 10.1111/nph.12021

Harvey, C. M., Li, Z., Tjellström, H., Blanchard, G. J., and Sharkey, T. D. (2015). Concentration of isoprene in artificial and thylakoid membranes. J. Bioenerg. Biomembr. 47, 419-429. doi: 10.1007/s10863-015-9625-9

Haworth, M., Cosentino, S. L., Marino, G., Brunetti, C., Scordia, D., Testa, G., et al. (2016). Physiological responses of Arundo donax ecotypes to drought: a common garden study. Glob. Change Biol. Bioenergy 9, 132-143. doi: 10.1111/ gcbb. 12348

Jardine, K., Abrell, L., Kurc, S. A., Huxman, T., Ortega, J., and Guenther, A. (2010). Volatile organic compound emissions from Larrea tridentata (creosotebush). Atmos. Chem. Phys. 10, 12191-12206. doi: 10.5194/acp-10-12191-2010

Jardine, K., Chambers, J., Alves, E. G., Teixeira, A., Garcia, S., Holm, J., et al. (2014). Dynamic balancing of isoprene carbon sources reflects photosynthetic and photorespiratory responses to temperature stress. Plant Physiol. 166, 2051-2064. doi: 10.1104/pp.114.247494

Jardine, K. J., Meyers, K., Abrell, L., Alves, E. G., Serrano, A. M. Y., Kesselmeier, J., et al. (2013). Emissions of putative isoprene oxidation products from mango branches under abiotic stress. J. Exp. Bot. 64, 3669-3679. doi: 10.1093/jxb/ ert202

Jardine, K. J., Monson, R. K., Abrell, L., Saleska, S. R., Arneth, A., Jardine, A., et al. (2012). Within-plant isoprene oxidation confirmed by direct emissions of oxidation products methyl vinyl ketone and methacrolein. Glob. Change Biol. 18, 973-984. doi: 10.1093/jxb/ert202

Jones, C. A., and Rasmussen, R. A. (1975). Production of isoprene by leaf tissue. Plant Physiol. 55, 982-987. doi: 10.1104/pp.55.6.982

Khedive, E., Shirvany, A., Assareh, M. H., and Sharkey, T. D. (2017). In situ emission of BVOCs by three urban woody species. Urban For. Urban Green 21, 153-157. doi: 10.1016/j.ufug.2016.11.018

Kreuzwieser, J., Graus, M., Wisthaler, A., Hansel, A., Rennenberg, H., and Schnitzler, J. P. (2002). Xylem-transported glucose as an additional carbon source for leaf isoprene formation in Quercus robur. New Phytol. 156, 171-178. doi: 10.1046/j.1469-8137.2002.00516.x

Lahr, E. C., Schade, G. W., Crossett, C. C., and Watson, M. R. (2015). Photosynthesis and isoprene emission from trees along an urban-rural gradient in Texas. Global Change Biol. 21, 4221-4236. doi: 10.1111/gcb.13010

Laothawornkitkul, J., Paul, N. P., Vickers, C. E., Possell, M., Taylor, J. E., Mullineaux, P. M., et al. (2008). Isoprene emissions influence herbivore feeding decisions. Plant Cell Environ. 31, 1410-1415. doi: 10.1111/j.1365-3040.2008. 01849.x

Lathiere, J., Hewitt, C. N., and Beerling, D. J. (2010). Sensitivity of isoprene emission from terrestrial biosphere to 20th century changes in atmospheric CO2 concentration, climate, and land use. Glob. Biogeochem. Cycle 24, GB1004. doi: $10.1029 / 2009$ GB003548

Ling, Z. H., Guo, H., Lam Saunders, S. M., and Wang, T. (2014). Atmospheric photochemical reactivity and ozone production at two sites in Hong Kong: 
application of a master chemical mechanism-photochemical box model. J. Geophys. Res. Atmos. 119, 10567-10582. doi: 10.1002/2014JD021794

Llusià, J., Penuelas, J., Sardans, J., Owen, S. M., and Niinemets, U. (2010). Measurement of volatile terpene emission in 70 dominant vascular plant species in Hawaii: aliens emit more than native. Glob. Ecol. Biogeogr. 19, 863-874. doi: 10.1111/j.1466-8238.2010.00557.x

Loreto, F., Bagnoli, F., and Fineschi, S. (2009). One species, many terpenes: matching chemical and biological diversity. Trends Plant Sci. 14, 416-420. doi: 10.1016/j.tplants.2009.06.003

Loreto, F., Dicke, M., Schnitzler, J. P., and Turlings, T. C. (2014). Plant volatiles and the environment. Plant Cell Environ. 37, 1905-1908. doi: 10.1111/pce.12369

Loreto, F., and Fineschi, S. (2015). Reconciling functions and evolution of isoprene emission in higher plants. New Phytol. 206, 578-582. doi: 10.1111/nph.13242

Loreto, F., Förster, A., Dürr, M., Csiky, O., and Seufert, G. (1998). On the monoterpene emission under heat stress and on the increased thermotolerance of leaves of Quercus ilex L. fumigated with selected monoterpenes. Plant Cell Environ. 21, 101-107. doi: 10.1046/j.1365-3040.1998.00268.x

Loreto, F., Pinelli, P., Brancaleoni, E., and Ciccioli, P. (2004). 13C labeling reveals chloroplastic and extrachloroplastic pools of dimethylallyl pyrophosphate and their contribution to isoprene formation. Plant Physiol. 135, 1903-1907. doi: 10.1104/pp.104.039537

Loreto, F., and Schnitzler, J. P. (2010). Abiotic stresses and induced BVOCs. Trends Plant Sci. 15, 154-166. doi: 10.1016/j.tplants.2009.12.006

Loreto, F., and Velikova, V. (2001). Isoprene produced by leaves protects the photosynthetic apparatus against ozone damage, quenches ozone products, and reduces lipid peroxidation of cellular membranes. Plant Physiol. 127, 1781-1787. doi: 10.1104/pp.010497

Maja, M. M., Kasurinen, A., Holopainen, T., Julkunen-Tiitto, R., and Holopainen, J. K. (2016). The effect of warming and enhanced ultraviolet radiation on gender-specific emissions of volatile organic compounds from European aspen. Sci. Total Environ. 547, 153-157. doi: 10.1016/j.scitotenv.2015.12.114

Marino, G., Brunetti, C., Tattini, M., Romano, A., Biasioli, F., Tognetti, R., et al. (2017). Dissecting the role of isoprene and stress-related hormones (ABA and ethylene) in Populus nigra exposed to unequal root zone water stress. Tree Physiol. doi: 10.1093/treephys/tpx083 [Epub ahead of print].

Mayrhofer, S., Teuber, M., Zimmer, I., Louis, S., Fischbach, R. J., and Schnitzler, J. P. (2005). Diurnal and seasonal variation of isoprene biosynthesis-related genes in grey poplar leaves. Plant Physiol. 139, 474-484. doi: 10.1104/pp.105.066373

Mithofer, A., and Boland, V. (2012). Plant defense against herbivores: chemical aspects. Ann. Rev. Plant Biol. 63, 431-450. doi: 10.1146/annurev-arplant042110-103854

Monson, R. K. (2002). Volatile organic compound emissions from terrestrial ecosystems: a primary biological control over atmospheric chemistry. Isr. J. Chem. 42, 29-42. doi: 10.1560/0JJC-XQAA-JX0G-FXJG

Monson, R. K., Jones, R. T., Rosenstiel, T. N., and Schnitzler, J. P. (2013). Why only some plants emit isoprene. Plant Cell Environ. 36, 503-516. doi: 10.1111/pce. 12015

Morfopoulos, C., Prentice, I. C., Keenan, T. F., Friedlingstein, P., Medlyn, B. E., Peñuelas, J., et al. (2013). A unifying conceptual model for the environmental responses of isoprene emissions from plants. Ann. Bot. 112, 1223-1238. doi: $10.1093 / \mathrm{aob} / \mathrm{mct} 206$

Morfopoulos, C., Sperlich, D., Penuelas, J., Filella, I., Llusia, J., Medlyn, B. E., et al. (2014). A model of plant isoprene emission based on available reducing power captures responses to atmospheric CO2. New Phytol. 203, 125-139. doi: $10.1111 /$ nph.12770

Mori, J., Saebo, A., Hanslin, H. M., Teani, A., Ferrini, F., Fini, A., et al. (2015). Deposition of traffic-related air pollutants on leaves of six evergreenshrub species during a Mediterranean summer season. Urban For. Urban Green. 14, 264-273. doi: 10.1016/j.ufug.2015.02.008

Niinemets, Ü., and Reichstein, M. (2003). Controls on the emission of plant volatiles through stomata: differential sensitivity of emission rates to stomatal closure explained. J. Geophys. Res. Atoms. 108, 4208. doi: 10.1029/ 2002JD002620

Niinemets, Ü., and Sun, Z. (2015). How light, temperature, and measurement and growth [CO2] interactively control isoprene emission in hybrid aspen. J. Exp. Bot. 66, 841-851. doi: 10.1093/jxb/eru443

Owen, S. M., Hewitt, C. N., and Rowland, C. S. (2013). "Scaling emissions from agroforestry plantations and urban habitats," in Biology, Controls and Models of
Tree Volatile Organic Compound Emissions, eds U. Niinemets and R. K. Monson (Berlin: Springer), 415-450.

Owen, S. M., and Peñuelas, J. (2005). Opportunistic emissions of volatile isoprenoids. Trends Plant Sci. 10, 420-426. doi: 10.1016/j.tplants.2005.07.010

Pegoraro, E., Rey, A., Greenberg, J., Harley, P., Grace, J., Malhi, Y., et al. (2004). Effect of drought on isoprene emission rates from leaves of Quercus virginiana Mill. Atmos. Environ. 38, 6149-6156. doi: 10.1016/j.atmosenv.2004.07.028

Pike, R. C., and Young, P. J. (2009). How plants can influence tropospheric chemistry: the role of isoprene emission from biosfere. Weather 64, 332-336. doi: $10.1002 /$ wea. 416

Pollastri, S., Tsonev, T., and Loreto, F. (2014). Isoprene improves photochemical efficiency and enhances heat dissipation in plants at physiological temperatures. J. Exp. Bot. 65, 1565-1570. doi: 10.1093/jxb/eru033

Rasulov, B., Hüve, K., Bichele, I., Laisk, A., and Niinemets, Ü (2010). Temperature response of isoprene emission in vivo reflects a combined effect of substrate limitations and isoprene synthase activity: a kinetic analysis. Plant Physiol. 154, 1558-1570. doi: 10.1104/pp.110.162081

Reich, P. B. (2014). The world-wide 'fast-slow' plant economics spectrum: a traits manifesto. J. Ecol. 102, 275-301. doi: 10.1111/1365-2745.12211

Rosenstiel, T. N., Potosnak, M. J., Griffin, K. L., Fall, R., and Monson, R. K. (2003). Increased $\mathrm{CO} 2$ uncouples growth from isoprene emission in an agriforest ecosystem. Nature 421, 256-259. doi: 10.1038/nature01312

Ryan, A. C., Hewitt, C. N., Possell, M., Vickers, C. E., Purnell, A., Mullineaux, P. M., et al. (2014). Isoprene emission protects photosynthesis but reduces plant productivity during drought in transgenic tobacco (Nicotiana tabacum) plants. New Phytol. 201, 205-216. doi: 10.1111/nph.12477

Schnitzler, J. P., Graus, M., Kreuzwieser, J., Heizmann, U., Rennenberg, H., Wisthaler, A., et al. (2004). Contribution of different carbon sources to isoprene biosynthesis in poplar leaves. Plant Physiol. 135, 152-160. doi: 10.1104/pp.103. 037374

Sharkey, T. D., and Monson, R. K. (2014). The future of isoprene emission from leaves, canopies and landscapes. Plant Cell Environ. 37, 1727-1740. doi: 10. $1111 /$ pce.12289

Sharkey, T. D., and Monson, R. K. (2017). Isoprene research - 60 years later, the biology is still enigmatic. Plant Cell Environ. doi: 10.1111/pce.12930 [Epub ahead of print].

Sharkey, T. D., Wiberley, A. E., and Donohue, A. R. (2008). Isoprene emission from plants: why and how. Annu. Bot. 101, 5-18. doi: 10.1093/aob/mcm240

Sharkey, T. D., and Yeh, S. (2001). Isoprene emission from plants. Ann. Rev. Plant Biol. 52, 407-436. doi: 10.1146/annurev.arplant.52.1.407

Sillman, S. (1999). The relation between ozone, NOx and hydrocarbons in urban and polluted rural environments. Atmos. Environ. 33, 1821-1845. doi: 10.1016/ S1352-2310(98)00345-8

Singsaas, E. L., Lerdau, M., Winter, K., and Sharkey, T. D. (1997). Isoprene increases thermotolerance of isoprene-emitting species. Plant Physiol. 115, 1413-1420. doi: 10.1104/pp.115.4.1413

Siwko, M. E., Marrink, S. J., de Vries, A. H., Kozubek, A., Uiterkamp, A. J. S., and Mark, A. E. (2007). Does isoprene protect plant membranes from thermal shock? A molecular dynamics study. Biochim. Biophys. Acta BBA 1768, 198-206. doi: 10.1016/j.bbamem.2006.09.023

Staudt, M., Morin, X., and Chuine, I. (2016). Contrasting direct and indirect effects of warming and drought on isoprenoid emissions from Mediterranean oaks. Reg. Environ. Change. doi: 10.1007/s10113-016-1056-6 [Epub ahead of print].

Tani, A., Tozaki, D., Okumura, M., Nozoe, S., and Hirano, T. (2011). Effect of drought stress on isoprene emission from two major Quercus species native to East Asia. Atmos. Environ. 45, 6261-6266. doi: 10.1016/j.atmosenv.2011.08.003

Tattini, M., Loreto, F., Fini, A., Guidi, L., Brunetti, C., Velikova, V., et al. (2015). Isoprenoids and phenylpropanoids are part of the antioxidant defense orchestrated daily by drought-stressed Platanus $\times$ acerifolia plants during Mediterranean summers. New Phytol. 207, 613-626. doi: 10.1111/nph.13380

Tattini, M., Velikova, V., Vickers, C., Brunetti, C., Di Ferdinando, M., Trivellini, A., et al. (2014). Isoprene production in transgenic tobacco alters isoprenoid, non-structural carbohydrate and phenylpropanoid metabolism, and protects photosynthesis from drought stress. Plant Cell Environ. 37, 1950-1964. doi: $10.1111 /$ pce. 12350

United Nations (2015). Sustainable Development Goals. Available at: www.un. org/sustainabledevelopment/sustainable-development-goals [accessed June 13, 2016]. 
Vanzo, E., Jud, W., Li, Z., Albert, A., Domagalska, M. A., Ghirardo, A., et al. (2017). Facing the future: Effects of short-term climate extremes on isoprene-emitting and nonemitting poplar. Plant Physiol. 169, 560-575. doi: 10.1104/pp.15. 00871

Velikova, V., Brunetti, C., Tattini, M., Doneva, D., Ahrar, M., Tsonev, T., et al. (2016). Physiological significance of isoprenoids and phenylpropanoids in drought response of Arundinoideae species with contrasting habitats and metabolism. Plant Cell Environ. 39, 2185-2197. doi: 10.1111/pce. 12785

Velikova, V., Edreva, A., and Loreto, F. (2004). Endogenous isoprene protects Phragmites australis leaves against singlet oxygen. Physiol. Plant. 122, 219-225. doi: 10.1111/j.0031-9317.2004.00392.x

Velikova, V., Ghirardo, A., Vanzo, E., Merl, J., Hauck, S. M., and Schnitzler, J. P. (2014). Genetic manipulation of isoprene emissions in poplar plants remodels the chloroplast proteome. J. Proteome Res. 13, 2005-2018. doi: $10.1021 /$ pr401124z

Velikova, V., Müller, C., Ghirardo, A., Theresa, M. R., Aichler, M., Walch, A., et al. (2015). Knocking down of isoprene emission modifies the lipid matrix of thylakoid membranes and influences the chloroplast ultrastructure in poplar. Plant Physiol. 168, 859-870. doi: 10.1104/pp.15. 00612

Velikova, V., Várkonyi, Z., Szabó, M., Maslenkova, L., Nogues, I., Kovács, L., et al. (2011). Increased thermostability of thylakoid membranes in isoprene-emitting leaves probed with three biophysical techniques. Plant Physiol. 157, 905-916. doi: 10.1104/pp.111.182519

Vickers, C. E., Gershenzon, J., Lerdau, M. T., and Loreto, F. (2009). A unified mechanism of action for volatile isoprenoids in plant abiotic stress. Nat. Chem. Biol. 5, 283-291. doi: 10.1038/nchembio. 158
Ying, Q., Li, J., and Kota, S. H. (2015). Significant contributions of isoprene to summertime secondary organic aerosol in Eastern United States. Environ. Sci. Technol. 49, 7834-7842. doi: 10.1021/acs.est.5b02514

Zeinali, N., Altarawneh, M., Li, D., Al-Nu'airat, J., and Dlugogorski, B. Z. (2016). New mechanistic insights: why do plants produce isoprene? ACS Omega 1, 220-225. doi: 10.1021/acsomega.6b00025

Zeng, G., Pyle, J. A., and Young, P. J. (2008). Impacts of climate change on tropospheric ozone and its global budget. Atmos. Chem. Phys. 8, 369-387. doi: 10.5194/acp-8-369-2008

Zenone, T., Hendriks, C., Brilli, F., Fransen, E., Gioli, B., Portillo-Estrada, M., et al. (2016). Interaction between isoprene and ozone fluxes in a poplar plantation and its impact on air quality at the European level. Sci. Rep. 6:32676. doi: $10.1038 /$ srep32676

Zhang, J., and Davies, W. J. (1987). Increased synthesis of ABA in partially dehydrated root tips and ABA transport from roots to leaves. J. Exp. Bot. 38, 2015-2023. doi: 10.1093/jxb/38.12.2015

Conflict of Interest Statement: The authors declare that the research was conducted in the absence of any commercial or financial relationships that could be construed as a potential conflict of interest.

Copyright (C) 2017 Fini, Brunetti, Loreto, Centritto, Ferrini and Tattini. This is an open-access article distributed under the terms of the Creative Commons Attribution License (CC BY). The use, distribution or reproduction in other forums is permitted, provided the original author(s) or licensor are credited and that the original publication in this journal is cited, in accordance with accepted academic practice. No use, distribution or reproduction is permitted which does not comply with these terms. 